\title{
Ethnopharmacological uses, phytochemistry, pharmacology, and toxicology of Olax subscorpioidea Oliv (Olacaceae): a review
}

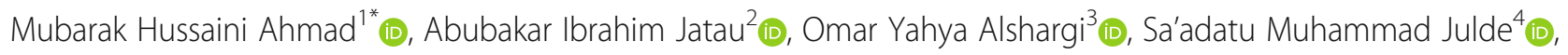
Mustapha Mohammed ${ }^{5,6}$ (D) Surajuddeen Muhammad ${ }^{7}$, Sagir Mustapha ${ }^{1,8}$ (D) Auwal Adam Bala ${ }^{4,9}$ (D),

Abubakar Sadiq Wada ${ }^{4}$, Musa Aminu ${ }^{1}$ and Abba Musab Usman ${ }^{10}$

\begin{abstract}
Background: The plant Olax subscorpioidea Oliv (Olacaceae) is a shrub that is widely available in Africa. It has been used in traditional medicine to treat various diseases including asthma, pain, inflammation, gastrointestinal and central nervous system (CNS) disorders, cough, diabetes mellitus, cancer, infectious diseases, hepatic diseases, and many other diseases. Several phytochemical and pharmacological investigations were conducted on this plant. However, comprehensive information on this medicinally important plant is not available in the literature. Therefore, in this review, we aimed to provide comprehensive and critical information on all the reported ethnomedicinal uses, phytochemistry, pharmacological activities, and potential toxicity of Olax subscorpioidea to highlight its therapeutic potentials based on traditional usage and identify research gaps as a basis for further investigations to develop novel therapeutic compounds.

Main body: The available information about the plant was retrieved from the online bibliographic databases (PubMed and Google Scholar) and published PhD dissertation using the search terms Olax subscorpioidea, traditional uses, ethnomedicinal uses, phytochemistry, pharmacology, toxicology, and safety. Phytochemical studies have shown that the plant contains several bioactive compounds such as rutin, morin, quercetin, caffeic acid, santalbic acid, n-hexadecanoic acid, squalene, nonacosane, hentriacontane, and many more compounds. Also, pharmacological investigations revealed that Olax subscorpioidea has antidepressant, antiepileptic, anti-Alzheimer's, cytotoxic, antioxidant, antihyperlipidemic, analgesic, antiinflammatory, antiarthritic, antidiabetic, anticancer, antiulcer, antimicrobial, hepatoprotective, apoptotic, antiprotease, and other CNS effects.

Conclusion: Several pharmacological studies on Olax subscorpioidea have established its ethnopharmacological uses. However, there are limited phytochemical and pharmacological studies to validate other folkloric claims of the plant. Therefore, extensive phytochemical and further pre-clinical efficacy and safety evaluations to fully establish its therapeutic potentials and elucidate its mechanisms of pharmacological actions could be necessary.
\end{abstract}

Keywords: Bioactive compounds, Ethnomedicinal uses, Medicinal plants, Olax subscorpioidea, Pharmacology, Phytochemistry

\footnotetext{
* Correspondence: mubarakhussainiahmad@gmail.com

ResearchGate: https://www.researchgate.net/profile/Mubarak_Hussaini_

Ahmad

'Department of Pharmacology and Therapeutics, Ahmadu Bello University,

Zaria, Kaduna, Nigeria

Full list of author information is available at the end of the article
}

\section{Springer Open}

(c) The Author(s). 2021 Open Access This article is licensed under a Creative Commons Attribution 4.0 International License, which permits use, sharing, adaptation, distribution and reproduction in any medium or format, as long as you give appropriate credit to the original author(s) and the source, provide a link to the Creative Commons licence, and indicate if changes were made. The images or other third party material in this article are included in the article's Creative Commons licence, unless indicated otherwise in a credit line to the material. If material is not included in the article's Creative Commons licence and your intended use is not permitted by statutory regulation or exceeds the permitted use, you will need to obtain permission directly from the copyright holder. To view a copy of this licence, visit http://creativecommons.org/licenses/by/4.0/. 


\section{Background}

Medicinal plants have been used for many years to prevent and manage diseases [1]. These medicinal plants have gained attention in traditional medicine and remain the primary source of naturally occurring drugs used in many communities worldwide [2]. Approximately 30\% of the currently available drugs contain bioactive compounds obtained from medicinal plants [3]. The World Health Organization (WHO) has reported that approximately $80 \%$ of the global population relies on medicinal plants for their primary health care needs [4]. Traditional knowledge of naturally occurring products from plant sources serves as a source of nutraceuticals and plays a vital role in drug discovery and development [5]. The use of natural products, including medicinal plants as therapeutic agents, faces numerous challenges, including lack of standardization, inadequate identification, and isolation of the bioactive compounds and lack of elucidation of mechanisms of pharmacological activities and clinical trials [6].

The plant Olax subscorpioidea Oliv is a shrub or tree that belongs to the family Olacaceae. It is up to $10 \mathrm{~m}$ or more in height. The plant is widely distributed in Nigeria, Zaire, Senegal, and other parts of Africa [7]. The plant is a woody shrub with leafy branches, its flowers are whitish, and the fruits are round and bright yellow when ripe. The plant is commonly known in different African languages as Ifon or Ufon in Yoruba; Gwaanon kurmii or Gwaanon raafii in Hausa; Igbulu, Atu-ogili, or Osaja in Igbo; Ukpakon in Edo; Ocheja in Igala; Aziza in Nsukka; and Mtungapwezi in Swahili $[8,9]$. The plant Olax subscorpioidea in its natural habitat is illustrated in Fig. 1.

Several scientific studies were conducted to evaluate the bioactive compounds and therapeutic potentials of Olax subscorpioidea. However, there is no summarized information on the ethnomedicinal uses, phytochemistry, and pharmacological properties of the plant to our knowledge. Therefore, this review summarizes the ethnomedicinal

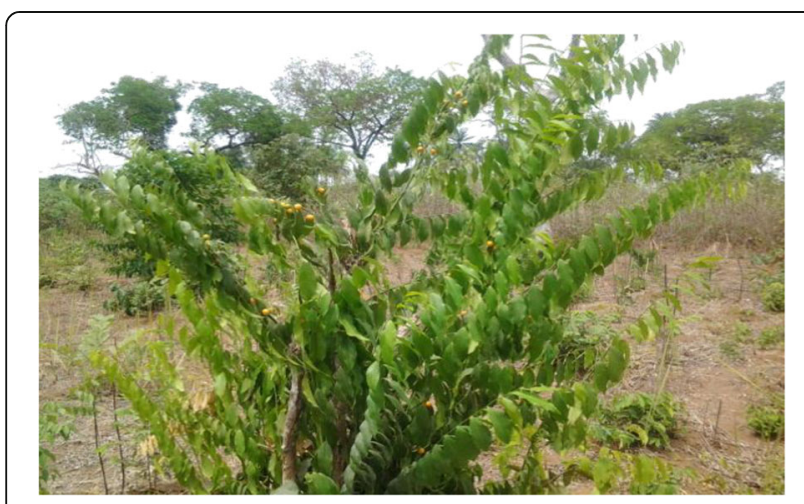

Fig. 1 Olax subscorpioidea in its natural habitat uses, phytochemical components, pharmacological properties, and toxicological studies of $O$. subscorpioidea. We have also identified research potentials of the plant that could be explored in the future.

\section{Botanical classification of Olax subscorpioidea}

Kingdom: Plantae; Subkingdom: Tracheobionta; Superdivision: Spermatophyta; Division: Magnoliophyta; Class: Magnoliopsida; Subclass: Rosidae; Order: Santalales; Family: Olacaceae; Genus: Olax; Species: subscorpioidea [10].

\section{Main text}

\section{Ethnopharmacological uses}

The roots of Olax subscorpioidea have been used as an aphrodisiac and are topically applied to treat cutaneous and subcutaneous parasitic infections in Nigeria [11]. The roots or the stem bark of the plant are also used as a chewing stick and preparations of dento-oral herbal remedies in the Western part of Nigeria for oro-dental hygiene [12]. Additionally, the plant roots have been used to manage inflammatory and mental diseases, convulsion, pain, and cancer in Nigeria [13]. The roots are used as a decoction against diabetes mellitus and obesity $[14,15]$ and asthma in South-Western Nigeria and as a recipe for the management of cancer [11, 16], malaria [17], constipation, diarrhoea, and gastric ulcer [8].

The decoction of the stem, bark, and leaves of the plant has been used in the Congo Republic against rheumatism and articular pains [18], venereal diseases, and guinea worms [19]. The whole plant of Olax subscorpioidea is used alone or in combination with Eleusine indica in the northern part of Nigeria to manage anxiety, mental disorders, and infectious diseases [13, 20]. The leaves, twig, and bark are used against arthritis, rheumatism, hepatic diseases, sexually transmitted diseases (STDs), and fever and as antidotes against venomous stings and bites [21]. The leaves of Olax subscorpioidea have been used in traditional medicine in Nigeria to manage Alzheimer's disease [22] and depression [23].

The Fruits, seeds, roots, bark, and leaves are used as a decoction in Nigeria and Cameroon to treat constipation, yellow fever, jaundice, venereal diseases, and guinea worm [19, 24]. Various parts of the plant are used in Nigeria to treat arthritis, constipation, cough, dermatosis, fever, headaches, jaundice, malaria, rheumatism, syphilis, ulcer, and many other diseases [25]. The herbal concoction of Olax subscorpioidea is used in the management of postpartum haemorrhage [26]. The plant is also used in combination with Tetrapleura tetrapteru and other plant material to manage infantile seizure [26]. The combined herbal concoction of Olax subscorpioidea, Fagara zanthoxyloides, and T. tetraptera, together with other plant material, is used to treat syphilis, stomach disorders, and gonorrhoea [26]. The summary 
of the reported ethnopharmacological uses of different parts of Olax subscorpioidea is presented in Table 1.

\section{Phytochemistry \\ Preliminary phytochemical contents of Olax subscorpioidea}

Preliminary phytochemical screening of the methanol leaf extract of Olax subscorpioidea and its fractions (aqueous, butanol, hexane, and ethyl-acetate) revealed the presence of saponins, tannins, steroids, cardiac glycosides, flavonoids, alkaloids, terpenoids, phenols, and carbohydrates [35, 37, 38]. Kazeem et al. reported cardiac glycosides, flavonoids, phenols, phlobatannins, terpenoids, alkaloids, steroids, and tannins in the hexane, ethyl-acetate, and acetone leaf extract of Olax subscorpioidea [15]. The plant's ethanol leaf extract showed carbohydrates, flavonoids, phenol, steroids, tannins, and terpenoids [25]. Ishola et al. found tannins, saponins, anthraquinones, phlobatannins, steroids, cardiac glycoside, polyphenols, reducing sugars, deoxysugar, cardenolides, and flavonoids in the aqueous leaf extract of the plant [23].

The methanol root extract of the plant revealed the presence of glycosides, terpenoids, alkaloids, and steroids [8]. Additionally, Popoola et al. reported tannins, alkaloids, saponins, flavonoids, cardiac glycosides, phenols, terpenoids, and reducing sugars in the hydro-ethanolic root extract of the plant [33].

Ayandele and Adebiyi (2007) reported the presence of tannins, glycosides, and saponins in the aqueous stem bark extract of Olax subscorpioidea, while tannins, alkaloids, glycosides, flavonoids, and steroids were present in the ethanol stem bark extract of the plant [7]. The methanol stem bark extract of Olax subscorpioidea was reported to contain alkaloids, saponins, tannins, cardiac glycosides, terpenoids, and phenols [12]. Fankam et al. reported alkaloids, anthraquinones, flavonoids, phenols, tannins, and triterpenes in the methanol fruit extract of the Olax subscorpioidea [39].

Quantitative phytochemical analysis of Olax subscorpioidea Quantitative phytochemical contents of Olax subscorpioidea are shown in Table 2.

\section{Elemental contents of Olax subscorpioidea}

The mineral elements present in herbal medicines are essential supplements to the bioactive compounds and are closely related to the effectiveness and potential toxic effects of traditional remedies [43]. The elemental analysis of the root and leaf extract of Olax subscorpioidea revealed the presence of calcium, copper, manganese, magnesium, sodium, zinc, potassium, aluminium, silicon, phosphorus, sulphur, chlorine, iron, cobalt, nickel, bromine, rubidium, and strontium $[25,40]$.

\section{Chemical compounds isolated and identified from Olax subscorpioidea}

The butanol leaves' fraction of Olax subscorpioidea revealed rutin, morin, quercetin, and caffeic acid [31]. Oladipupo et al. identified the presence of $\mathrm{n}$-hexadecanoic acid (17.6\%), 7,10,13-hexadecatrienoic acid, methyl ester (0.84\%), 9,17-octadecadienal, (Z)- (2.87\%), 9,12-octadecadienoic acid (Z,Z)- (18.0\%), octadecanoic acid (4.05\%), squalene (4.12\%), nonacosane (5.54\%), and hentriacontane $(1.22 \%)$ in the $\mathrm{n}$-hexane leaf extract of the plant [44]. Additionally, santalbic acid was isolated from the methanol seed fraction of Olax subscorpioidea [45]. The phytochemical constituents identified and isolated from Olax subscorpioidea are illustrated in Table 3. The chemical structures of the major isolated compounds from Olax subscorpioidea are presented in Fig. 2.

\section{Pharmacological activities of Olax subscorpioidea}

The extracts and fractions of various parts of Olax subscorpioidea were screened for various pharmacological activities, namely antidepressant, anticonvulsant, sedative, anxiolytic, anti-Alzheimer's, cytotoxicity, antioxidant, hypolipidemic, analgesic, antiinflammatory, antiarthritic, hypoglycaemic, antiulcer, anticancer, antimicrobial, anthelmintic, hepatoprotective, apoptotic, and antiprotease activities. The summary of the reported pharmacological activities of different extracts and fractions obtained from various parts of Olax subscorpioidea are presented in Table 4.

\section{Antidepressant activity}

The ethanol leaf extract of Olax subscorpioidea significantly reduced the immobility time in forced swimming test (FST) and tail suspension test (TST) and reduced the number of crossing activity in the open field test (OFT) [13]. The results also demonstrated a significant reduction in diarrhoea in the reserpine model of depression [13]. Adeoluwa et al. reported the possible involvement of adrenergic, dopaminergic, and serotonergic systems in the antidepressant activity of Olax subscorpioidea [31]. Several antidepressant drugs such as tricyclic antidepressants and monoamine oxidase inhibitors reduce immobility time [46]. Also, antidepressant drugs including imipramine blocked reserpine-induced diarrhoea [47]. Studies have shown a correlation between adrenergic dysfunction and pathophysiology of depression $[48,49]$. The $(\alpha 1$ and $\alpha 2)$-adrenergic system serves as a target for the antidepressant drugs [50]. Previous research by Yamada et al. reported the antidepressant action of drugs via dopaminergic system [51]. The serotonin reuptake inhibitors increase the synaptic concentration of serotonin [52] Therefore, the results justified the traditional use of the Olax subscorpioidea in the management of mental illness, including depression. 
Table 1 Ethnopharmacological uses of Olax subscorpioidea and scientific confirmation of their pharmacological activity

\begin{tabular}{|c|c|c|c|}
\hline Ethnomedicinal uses & Plant part & References & Confirmation of pharmacological activity \\
\hline Alzheimer's disease & Leaves & {$[22]$} & Confirmed [22] \\
\hline Antidote against venomous stings and bites & Leaves, twig, and bark & {$[21]$} & Not confirmed \\
\hline Anxiety & Whole plant & {$[20]$} & Not confirmed \\
\hline Aphrodisiac & Roots & {$[11]$} & Not confirmed \\
\hline Arthritis & Leaves, twig, and bark & {$[21]$} & Confirmed [27] \\
\hline Asthma & Roots & {$[16]$} & Not confirmed \\
\hline Cancer & Roots & {$[18]$} & Confirmed [28] \\
\hline Constipation & Fruit, seed, root, bark & {$[8,19,24]$} & Not confirmed \\
\hline Convulsion & Roots and leaves & {$[13]$} & Confirmed $[29,30]$ \\
\hline Cough & Whole plant & {$[25]$} & Not confirmed \\
\hline Dental diseases & Stem or roots & {$[12]$} & Not confirmed \\
\hline Depression & Leaves & {$[23]$} & Confirmed $[13,31]$ \\
\hline Dermatosis & Whole plant & {$[25]$} & Not confirmed \\
\hline Diabetes mellitus & Roots & {$[14,15]$} & Confirmed $[15,32]$ \\
\hline Diarrhoea & Roots & {$[8]$} & Not confirmed \\
\hline Fever & Leaves, twig, and bark & {$[21]$} & Not confirmed \\
\hline Gonorrhoea & Not specified & {$[26]$} & Not confirmed \\
\hline Guinea worm & Bark or leaves & {$[19]$} & Not confirmed \\
\hline Headache & Whole plant & {$[25]$} & Not confirmed \\
\hline Hepatic diseases & Leaves, twig, and bark & {$[21]$} & Confirmed [21] \\
\hline Inflammation & Roots & {$[18]$} & Confirmed $[23,30,33]$ \\
\hline Infectious diseases & Whole plant & {$[20]$} & Confirmed $[7,12,24,25,34]$ \\
\hline Jaundice & Whole plant & {$[24,25]$} & Not confirmed \\
\hline Malaria & Roots & {$[17,25]$} & Not confirmed \\
\hline Obesity & Roots & {$[14]$} & Confirmed [14] \\
\hline Pain & Leaves & {$[21]$} & Confirmed $[18,23,33,35]$ \\
\hline Parasitic infections & Roots & {$[11]$} & Confirmed [36] \\
\hline Postpartum haemorrhage & Not specified & {$[26]$} & Not confirmed \\
\hline Rheumatism & Stem and leaves & {$[18]$} & Not confirmed \\
\hline Sexually transmitted diseases & Leaves, twig, and bark & {$[9,21]$} & Not confirmed \\
\hline Syphilis & Whole plant & {$[25]$} & Not confirmed \\
\hline Typhoid & Roots & {$[14]$} & Not confirmed \\
\hline Ulcer & Roots & {$[8]$} & Confirmed [8] \\
\hline Yellow fever & Leaves & [9] & Not confirmed \\
\hline
\end{tabular}

\section{Anti-Alzheimer's activity}

The aqueous leaf extract of Olax subscorpioidea demonstrated promising inhibitory effects against acetylcholinesterase $(\mathrm{AChE})$ and butyrylcholinesterase (BChE) [22]. Therefore, the plant can potentially manage Alzheimer's disease due to its inhibitory action on the key enzymes (AChE and $\mathrm{BChE}$ ) associated with the disease [22].

\section{Anticonvulsant activity}

The ethanol and methanol leaf extracts of Olax subscorpioidea significantly delayed the onset of seizures and death latency, which provided the scientific basis for using the plant in traditional medicine for the management of convulsion which could be due to the enhancement of gamma-aminobutyric acid (GABA) [29, 30].

\section{Sedative effects}

The ethanol leaf extract of Olax subscorpioidea produced a significant and dose-dependent reduction in rearing and grooming frequency, suggestive of its sedative and stress attenuating effects due to its interaction with $\alpha_{2}$-adrenergic pathway [29]. The extract at $25 \mathrm{mg} / \mathrm{kg}$ also significantly 
Table 2 Quantitative phytochemical contents of Olax subscorpioidea

\begin{tabular}{|c|c|c|c|}
\hline Plant part & Solvent & Phytochemical & Reference \\
\hline Root & Powdered form & $\begin{array}{l}\text { Alkaloids }(0.61 \%) \text {, anthraquinones }(0.1 \%) \text {, cardiac glycosides }(0.24 \%) \text {, saponins }(0.27 \%) \text {, } \\
\text { tannins }(0.03 \%) \text { and polyphenols }(0.14 \%)\end{array}$ & [40] \\
\hline Root & Aqueous and ethanol & $\begin{array}{l}\text { Tannins }(4.72 \% \text { and } 4.91 \%) \text {, terpenoids }(0.285 \% \text { and } 3.32 \%) \text {, steroids }(2.12 \% \text { and } 3.58 \%) \text {, } \\
\text { alkaloids }(2.10 \% \text { and } 3.58 \%) \text {, saponins }(4.22 \% \text { and } 0.02 \%) \text {, phenols }(3.57 \% \text { and } 6.70 \%) \text {, } \\
\text { flavonoids }(2.35 \% \text { and } 3.45 \%) \text {, and carotenoids }(1.12 \% \text { and } 2.23 \%) \text { respectively }\end{array}$ & [27] \\
\hline Roots & Ethanol & $\begin{array}{l}\text { Saponins }(865.00 \mathrm{mg} / 100 \mathrm{~g}) \text {, alkaloids }(963.33 \mathrm{mg} / 100 \mathrm{~g}) \text {, tannins }(863.33 \mathrm{mg} / 100 \mathrm{~g}) \text {, } \\
\text { flavonoids }(636.67 \mathrm{mg} / 100 \mathrm{~g}) \text {, anthraquinones }(46.67 \mathrm{mg} / 100 \mathrm{~g}) \text {, Proanthocyanidins } \\
(2.67 \mathrm{mg} / \mathrm{g}) \text {, and total polyphenol content (TPC) }(38.77 \mathrm{GAE} / \mathrm{g})\end{array}$ & [14] \\
\hline Leaves & Aqueous & TPC (30 mg GAE/g) and total flavonoids content (4.26 mg QAE/g) & [22] \\
\hline \multirow[t]{2}{*}{ Leaves } & Aqueous and ethanol & $\begin{array}{l}\text { TPC (12.78 and } 35.49 \mathrm{GAE} / \mathrm{g}) \text {, total flavonoids ( } 4.01 \text { and } 22.69 \mathrm{QAE} / \mathrm{g}) \text {, flavonols } \\
\text { (1.35 and } 9.78 \mathrm{QAE} / \mathrm{g}) \text {, and proanthocyanidines (1.44 and } 1.99 \mathrm{QAE} / \mathrm{g} \text { ) }\end{array}$ & [41] \\
\hline & Methanol spice & phenols and triterpenes and a TPC (8.39 GAE/100 g of extract) & [42] \\
\hline
\end{tabular}

TPC total polyphenols content, GAE/g gallic acid equivalent per gram of the extract

reduced the locomotor activity in a similar manner to diazepam $(2 \mathrm{mg} / \mathrm{kg})$, indicative of its central nervous system (CNS) depressant effect [29]. Furthermore, the extract produced a significant and dose-dependent reduction in the number of head dip and prolonged the pentobarbitoneinduced sleeping time [29]. The study supports the folkloric claim of the plant in the management of mental illness.

\section{Anxiolytic effect}

The leaves of Olax subscorpioidea did not significantly alter the frequency of open arm entries and the percentage of open arm duration, which indicated its lack of anxiolytic effect [29]. Therefore, based on the reported traditional use of Olax subscorpioidea in the management of anxiety, other parts of the plant are recommended to be thoroughly screened for the folkloric claimed anxiolytic activity with other extracts or fractions that may contain potential anxiolytic compounds.

\section{Antihyperlipidemic activity}

The ethanol root extract of Olax subscorpioidea at 200 and $400 \mathrm{mg} / \mathrm{kg}$ significantly reduced the total cholesterol, triglycerides, and low-density lipoprotein and increased the high-density lipoprotein [14]. The result validated the lipid-lowering effect of the plant in the management of obesity in traditional medicine

\section{Cytotoxic activity}

Cantrell et al. reported the cytotoxicity effect of the methanol seed extract of Olax subscorpioidea. In the same study, santalbic acid isolated from the plant also showed remarkable cytotoxicity [45].

\section{Antioxidant activity}

The aqueous leaf extract of Olax subscorpioidea exerted 2, 2-azino-bis-3-ethylbenthiazoline-6-sulphonic acid (ABTS) scavenging activity, iron chelating and reducing effects, and iron-induced lipid peroxidation due to the presence

Table 3 Chemical compounds isolated and identified from Olax subscorpioidea and their reported pharmacological activities

\begin{tabular}{|c|c|c|c|c|}
\hline Compound & Plant part & Solvent & Activity & References \\
\hline Rutin & Leaves & Butanol & NP & [31] \\
\hline Morin & Leaves & Butanol & NP & [31] \\
\hline Quercetin & Leaves & Butanol & NP & [31] \\
\hline Caffeic acid & Leaves & Butanol & NP & [31] \\
\hline n-Hexadecanoic acid & Leaves & n-hexane & NP & [44] \\
\hline 7,10,13-Hexadecatrienoic acid, methyl ester & Leaves & n-hexane & NP & [44] \\
\hline 9,17-Octadecadienal, (Z)- & Leaves & n-hexane & NP & [44] \\
\hline 9,12-Octadecadienoic acid (Z,Z)- & Leaves & n-hexane & NP & [44] \\
\hline Octadecanoic acid & Leaves & n-hexane & NP & [44] \\
\hline Squalene & Leaves & n-hexane & NP & [44] \\
\hline Nonacosane & Leaves & n-hexane & NP & [44] \\
\hline Hentriacontane & Leaves & n-hexane & NP & [44] \\
\hline Santalbic acid & Seed & Methanol & Cytotoxicity & [45] \\
\hline
\end{tabular}

NP no pharmacological screening reported 
<smiles>O=c1c(O)c(-c2ccc(O)c(O)c2)oc2cc(O)cc(O)c12</smiles>

Quercetin

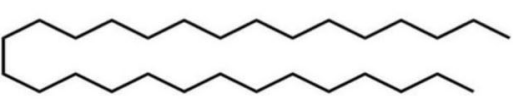

Nonacosane

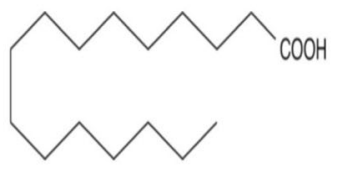

Hexadecanoic acid

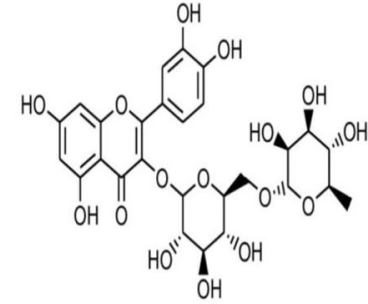

Rutin

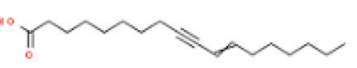

Santalbic acid<smiles>O=c1c(O)c(-c2ccc(O)cc2O)oc2cc(O)cc(O)c12</smiles>

Morin<smiles>CCCC=C(C)CCC=C(C)CCCC=C(C)CCC=C(C)C</smiles><smiles>O=C(O)/C=C/c1ccc(O)c(O)c1</smiles>

Caffeic acid

Fig. 2 Chemical structures of isolated compounds from Olaxsubscorpioidea

of high TPC [22]. The hydroethanolic leaf extract of Olax subscorpioidea produced a dose-dependent reduction in the levels of thiobarbituric acid reactive substances (TBARS) and increased the antioxidant power as well as 1 , 1-diphenyl-2-picryl-hydrazyl (DPPH) radical scavenging activity [21]. In another study conducted by Konan et al., the plant's ethanol and aqueous leaf extracts produced a significant radical scavenging activity, inhibitory effect on lipid peroxidation, and ferric ion chelating activity and reducing power [41].

The ethanol root extract of Olax subscorpioidea demonstrated a significant antioxidant effect against DPPH radicals [14, 28]. The hydro-alcoholic root extract of the plant also showed a significant effect against nitric oxide $(\mathrm{NO})$ radicals in a similar manner to ascorbic acid but higher than gallic acid [28]. In the same study, the extract significantly increased the levels of glutathione (GSH) and superoxide dismutase (SOD) and reduced the levels of malondialdehydes (MDA) [28]. The findings suggested that the plant can enhance the antioxidant activities of GSH and SOD and inhibit lipid peroxidation [28]. The methanol leaves and spice extract of Olax subscorpioidea elicited DPPH radical and hydroxyl radical scavenging activities and remarkable ferric reducing antioxidant power (FRAP) and total antioxidant capacity [32, 42].

\section{Analgesic activity}

The leaf extracts of Olax subscorpioidea showed a significant and dose-dependent reduction in the number of abdominal writhes and reduced pain responses [18, 37] suggestive of its central and peripheral analgesic activity [53]. Similarly, the extracts produced a significant increase in the pain latency in the hot plate test, which affirms its central analgesic property $[10,18]$. It was concluded that the analgesic action of the extract involves its interaction with the opioidergic system $[10,18]$.

In another study by Odoma et al., the hexane, butanol, and aqueous leaf fractions of Olax subscorpioidea produced a significant and dose-dependent reduction in the number of abdominal writhes and pain perception in formalin-induced paw licking [37]. The aqueous and butanol fractions also demonstrated a significant and doseand time-dependent increase in pain latency in hot plate test [37]. The mechanism of analgesic action of the butanol fraction was suggested to be due to its interaction with serotonergic and nitric oxide l-arginine pathways [9].

The aqueous leaf extract of Olax subscorpioidea showed a significant and non-dose-dependent reduction in the mean number of abdominal constrictions [23]. The extract at $50 \mathrm{mg} / \mathrm{kg}$ produced the highest activity $(68.28 \%)$ in a similar manner to the standard drug, ibuprofen $(67.74 \%)$. Also, at the dose of $200 \mathrm{mg} / \mathrm{kg}$, the 
Table 4 Reported pharmacological activities of Olax subscorpioidea

\begin{tabular}{|c|c|c|c|c|}
\hline Activity & Solvent & Plant part & Assay & References \\
\hline Antiarthritic & Aqueous, ethanol & Roots & In vivo & {$[42]$} \\
\hline Antidepressant & Ethanol and butanol & Leaves & In vivo & [13] \\
\hline Anticonvulsant & Ethanol and methanol & Leaves & In vivo & {$[29,30]$} \\
\hline Sedative & Ethanol & Leaves & In vivo & [29] \\
\hline Anti-Alzheimer & Aqueous & Leaves & In vitro & {$[22]$} \\
\hline Cytotoxicity & Methanol & Seeds & In vivo & {$[45]$} \\
\hline \multirow[t]{7}{*}{ Antioxidant } & Ethanol & Roots & In vitro & {$[14]$} \\
\hline & Aqueous & Leaves & In vitro & {$[22,41]$} \\
\hline & Hydroalcoholic & Roots & In vivo & {$[28]$} \\
\hline & Hydroethanolic & Leaves & In vivo & {$[21]$} \\
\hline & Methanol & Spices & In vivo & {$[42]$} \\
\hline & Ethanol & Leaves & In vitro & {$[41]$} \\
\hline & Methanol & Leaves & In vitro & {$[32]$} \\
\hline Antihyperlipidemic & Ethanol & Roots & In vivo & {$[14]$} \\
\hline \multirow[t]{7}{*}{ Analgesic } & Ethanol & Leaves & In vivo & [18] \\
\hline & Methanol & Leaves & In vivo & {$[35]$} \\
\hline & Hexane & Leaves & In vivo & [37] \\
\hline & Butanol & Leaves & In vivo & {$[37]$} \\
\hline & Aqueous & Leaves & In vivo & {$[23,37]$} \\
\hline & Hydroethanolic & Roots & In vivo & [33] \\
\hline & Butanol & Leaves & In vivo & {$[9]$} \\
\hline \multirow[t]{4}{*}{ Antiinflammatory } & Methanol & Leaves & In vivo & {$[35]$} \\
\hline & Hexane & Leaves & In vivo & {$[37]$} \\
\hline & Butanol & Leaves & In vivo & {$[37]$} \\
\hline & Aqueous & Leaves & In vivo & {$[23,37]$} \\
\hline \multirow[t]{5}{*}{ Antihyperglycaemic } & Acetone & Leaves & In vitro & {$[15]$} \\
\hline & Ethylacetate & Leaves & In vitro & {$[15]$} \\
\hline & Hexane & Leaves & In vitro & {$[15]$} \\
\hline & Hexane & Leaves & In vivo & {$[15]$} \\
\hline & Methanol & Leaves & In vivo & {$[32]$} \\
\hline Antiulcer & Methanol & Roots & In vivo & {$[8]$} \\
\hline Anticancer & Hydroalcoholic & Roots & In vitro and in vivo & {$[28]$} \\
\hline \multirow[t]{5}{*}{ Antimicrobial } & Methanol-dichloromethane & Fruit & In vivo and in vitro & {$[24]$} \\
\hline & Ethanol & Leaves & In vitro & {$[25]$} \\
\hline & Aqueous and ethanol & Stem & In vitro & {$[7]$} \\
\hline & Methanol & Stem bark & In vitro & {$[12]$} \\
\hline & Methanol & Seeds & In vitro & {$[34]$} \\
\hline Antihelmintic & Ethanol & Roots & In vitro & {$[36]$} \\
\hline Hepatoprotective & Hydroethanolic & Leaves & In vivo & {$[21]$} \\
\hline Apoptotic & Methanol & Leaves & In vitro & [38] \\
\hline
\end{tabular}

extract significantly reduced paw licking duration and biting in formalin-induced pain [23]. The extract at the doses of 50 and $400 \mathrm{mg} / \mathrm{kg}$ significantly and time-dependently increased the pain latency [23].
The authors concluded that the extract's probable mechanisms of analgesic activity involve its interaction with serotonergic, $K_{\text {ATP }}$ channels, and dopaminergic systems [23]. 
In another study conducted by Popoola et al. in 2016, the hydro-ethanolic root extract of Olax subscorpioidea significantly and dose-dependently reduced the number of abdominal constrictions [33]. Similarly, the extract at 200 and $400 \mathrm{mg} / \mathrm{kg}$ significantly reduced the paw licking in formalin-induced pain [33]. These findings validated the use of the plant in traditional medicine for the management of pain.

\section{Antiinflammatory activity}

The methanol leaf extract of Olax subscorpioidea and fractions (hexane, aqueous, and butanol) produced remarkable antiinflammatory effects [23, 37]. Moreover, the aqueous leaf extract of Olax subscorpioidea produced a significant and time-dependent reduction in the complete Freund's adjuvant (CFA)-induced chronic inflammation. The extract showed its maximum inhibitory effect $(85.30 \%)$ at $400 \mathrm{mg} / \mathrm{kg}$ similar to the standard antiinflammatory agent, celecoxib [23]. In a study conducted by Popoola et al. in 2016, the hydro-ethanolic root extract of Olax subscorpioidea showed a significant and dose-dependent antiinflammatory effect [33].

Research by Odoma et al. has shown that the aqueous and butanol leaf fractions of Olax subscorpioidea significantly reduced the concentrations of the proinflammatory cytokines, including interleukin- $1 \alpha$ (IL$1 \alpha$ ), vascular endothelial growth factor (VEGF), and epidermal growth factor (EGF); with no effect on tumour necrosis factor- $\alpha$ (TNF- $\alpha$ ) and IL-2 [54]. In contrast, the fractions stimulate the synthesis of antiinflammatory cytokines such as IL-5, IL-6, and interferon- $\gamma$ (IFN- $\gamma$ ) [54]. These findings validated the use of the plant in traditional medicine for the management of inflammatory disorders.

\section{Antiarthritic activity}

The aqueous and ethanol root extracts of Olax subscorpioidea significantly reduced the paw size, C-reactive protein, rheumatoid factor, erythrocyte sedimentation rate (ESR), and cytokines in a dose- and time-dependent manner compared to the arthritis-induced group [27]. The extracts also significantly reduced the synovial hyperplasia in a similar manner to indomethacin used as a standard agent [27]. The study validated the folkloric use of the plant in the management of rheumatoid arthritis.

\section{Antihyperglycaemic activity}

The hexane, ethyl-acetate, and acetone leaf extract of Olax subscorpioidea produced remarkable inhibitory effects on $\alpha$-amylase and $\alpha$-glucosidase, the critical enzymes associated with diabetes mellitus [15]. The hexane and ethyl-acetate extracts demonstrated higher inhibitory effects on $\alpha$-amylase than the standard hypoglycaemic agent, acarbose [27]. The hexane extract produced higher $\alpha$-glucosidase inhibitory activity than the acarbose [27]. In the same study, the hexane extract significantly reduced the postprandial blood glucose level [27].

Based on the study conducted by Ayoola et al., the methanol leaf extract of Olax subscorpioidea showed a non-significant hypoglycaemic effect in normoglycaemic rats, suggestive of its lack of hypoglycaemic effect on non-diabetic subjects [32]. The extract demonstrated a significant and dose- and time-dependent antihyperglycaemic effect higher than that of the glibenclamide [32]. Also, the aqueous fraction of the extract $(400 \mathrm{mg} / \mathrm{kg})$ demonstrated a similar antihyperglycaemic effect (36.87\%) to the glibenclamide (38.97\%) [32]. These findings validated the use of the plant in traditional medicine for the management of diabetes mellitus.

\section{Antiulcer activity}

The methanol root extract of Olax subscorpioidea produced dose-dependent ulcer protection, which was significant at the dose of $600 \mathrm{mg} / \mathrm{kg}$ in a similar manner to the standard drug sucralfate [8]. Therefore, the roots of the plant could have antiulcer activity as claimed in traditional medicine.

\section{Anticancer activity}

The hydro-alcoholic root extract of Olax subscorpioidea significantly and dose-dependently inhibited the growth of Allium cepa root [28]. The extract also produced a significant mito-depressive effect on the onion bulb similar to the standard anticancer drug, cyclophosphamide [28]. Additionally, the extract significantly increased the deoxyribonucleic acid (DNA)-damaging effect [28]. The result provided the potential chemopreventive and chemotherapeutic effect of the plant in traditional medicine against cancers [28].

\section{Antimicrobial activity}

The aqueous stem extract of Olax subscorpioidea demonstrated narrow-spectrum antimicrobial activity against Pseudomonas aeruginosa and Proteus vulgaris. In contrast, the plant's ethanol stem extract showed broadspectrum antimicrobial activity against Staphylococcus aureus, Escherichia coli, Pseudomonas aeruginosa, Proteus vulgaris, Salmonella spp., Aspergillus niger, and Aspergillus tamari [7].

The methanol seeds and stem bark extracts of Olax subscorpioidea produced remarkable antimicrobial activity against Aspergillus fumigatus and Staphylococcus aureus [34]. In other studies, the fruit extract of Olax subscorpioidea demonstrated remarkable antimicrobial activity against Candida albican, Cryptococcus neoformans, Candida tropicalis, Candida parapsilosis, Candida lusitaniae, Escherichia coli, Enterobacter aerogenes, 
Klebsiella pneumoniae, and Providencia stuartuii [24, 39]. Furthermore, the extract at $2000 \mathrm{mg} / \mathrm{kg}$ significantly decreased the fungal load in the blood and kidneys of the yeast-infected rats [24].

The ethanol leaf extract of Olax subscorpioidea produced significant and concentration-dependent inhibitory effect against Escherichia coli, Staphylococcus aureus, Pseudomonas aeruginosa, Klebsiella pneumoniae, Proteus mirabilis, Aspergillus niger, and Penicillium sp. [25]. The extract at $500 \mathrm{mg} / \mathrm{ml}$ showed better antifungal activity against Aspergillus niger and Penicillium sp. than the standard antifungal drug, fluconazole [25]. A previous research by Idowu et al. has shown that the methanol root extract of Olax subscorpioidea produced a concentrationdependent inhibitory effect against Bacillus anthracis, Pseudomonas aeruginosa, Proteus mirabilis, Staphylococcus aureus, and multi-drug resistant Escherichia coli implicated in urinary tract infection [55]. The roots of Olax subscorpioidea produced inhibitory effects against Shigella spp., Escherichia coli, and Proteus spp. [56].

The studies conducted on Olax subscorpioidea validated its use for the treatment of infectious diseases in traditional medicine. However, most of the studies concentrated on in vitro investigations. Therefore, more antimicrobial evaluations using in vivo assays should be conducted with specific microbial strains to validate these results. Furthermore, investigations are required to determine the plant's effects against multi-drug resistant microorganisms and evaluate its mechanisms of antimicrobial actions to develop novel antimicrobial agents.

\section{Antihelmintic activity}

Kone et al. reported the antihelmintic activity of the ethanol root extract of Olax subscorpioidea against Echinostoma caproni, Schistosoma mansoni, Trichuris muris, and Heligmosomoides bakeri [36]. The extract nonsignificantly reduced the total and female worm burden against Schistosoma mansoni [36]. Therefore, the result validated the use of the plant as a herbal remedy in the treatment of parasitic diseases such as helminthiasis.

\section{Hepatoprotective activity}

The hydro-ethanolic leaf extract of Olax subscorpioidea significantly reduced the levels of serum glutamate oxaloacetate transaminase (SGOT), glutamate pyruvate transaminase (SGPT), and alkaline phosphatase (ALP) compared with the carbon tetrachloride $\left(\mathrm{CCl}_{4}\right)$ intoxicated group [21]. The extract at the doses of 25 and 100 $\mathrm{mg} / \mathrm{kg}$ reduced the level of gamma-glutamyl transferase (GGT) and total bilirubin [21]. Also, the extract dosedependently increased the level of $\left(\alpha_{1}, \alpha_{2}, \beta\right.$, and $\left.\gamma\right)$ globulin [21]. The extract at the dose of $100 \mathrm{mg} / \mathrm{kg}$ revealed near-normal hepatic cells with a mild degree of inflammation and lesser fatty infiltration without necrosis compared to the $\mathrm{CCl}_{4}$-intoxicated animals [21]. The result validated the folkloric use of the plant for the management of liver diseases in traditional medicine.

\section{Apoptosis-induced activity}

The methanol leaf extract of Olax subscorpioidea induced mitochondrial membrane permeability transition pore opening [38]. The extract also significantly increased mitochondrial adenosine triphosphate (ATP) hydrolysis and produced significant mitochondrial membrane lipid peroxidation [38]. Therefore, the plant may contain bioactive components that could help manage diseases that require an enhanced rate of apoptosis, such as cancer [57].

\section{Antiprotease and membrane stabilizing activities}

The saline and alkaline extracts of Olax subscorpioidea demonstrated remarkable antitryptic and dose-dependent membrane stabilizing activities [26]. These findings justify the use of the plant in the treatment of inflammatoryrelated diseases.

\section{Phytotoxic activity}

Olubode et al. reported the inhibitory effect of the aqueous extracts of Olax subscorpioidea parts (leaf, seed, bark, stem, and root) on maize germination. The extract remarkably reduced seed germination, and significantly increased the number of leaves, plant height, and root and shoot dry weight. The finding revealed that the plant possesses alloallelopathic activity on seed maize that could be useful as bioherbicide [58].

\section{Toxicological studies on Olax subscorpioidea}

There has been an upsurge in the use of herbal medicines to treat many diseases. However, some naturally occurring chemical substances have potential toxicity effects, and their safety is an essential point of health concern [59]. In the process of drug development, there are various pre-clinical toxicity studies needed, including acute toxicity study, repeated dose toxicity study, genetic toxicity study, reproductive toxicity study, carcinogenicity study, and toxicokinetic evaluations [60]. Safety information on traditional herbal medicines consumed is vital as part of a response to public health concerns [4]. Yuet Ping et al. suggested the need to document experimental information on medicinal plants' safety profile and their extracts used in drug development [61]. Therefore, reports and data on medicinal plants' potentially toxic effects are vital in their development for therapeutic use [4].

\section{Acute toxicity on Olax subscorpioidea}

The intraperitoneal (i.p) median lethal dose $\left(\mathrm{LD}_{50}\right)$ of the methanol and ethanol leaf extract of Olax subscorpioidea was estimated to be $3800 \mathrm{mg} / \mathrm{kg}$ [30] and $300 \mathrm{mg} / \mathrm{kg}$ [29] 
respectively, while the oral $\mathrm{LD}_{50}$ of the methanol leaf extract of Olax subscorpioidea was estimated to be higher than $5000 \mathrm{mg} / \mathrm{kg}$ [35]. The acute toxicity study of the methanol root extract of Olax subscorpioidea showed an $\mathrm{LD}_{50}$ of $2154 \mathrm{mg} / \mathrm{kg}$ [8].

The hydro-ethanolic leaf extract of. Olax subscorpioidea $(500,1000,2000$, and $4000 \mathrm{mg} / \mathrm{kg}$ ) caused some behavioural changes and mortality in mice [21]. The extract also produced signs of acute toxicity, including agitation, aggression, body twisting, convulsion, and diarrhoea at 2000 and $4000 \mathrm{mg} / \mathrm{kg}$. Also, the $\mathrm{LD}_{50}$ of the extract was estimated to be $1000 \mathrm{mg} / \mathrm{kg}$ in mice [21].

The acute oral administration of the aqueous leaf extract of Olax subscorpioidea (500, 2500, and $5000 \mathrm{mg} /$ $\mathrm{kg}$ ) did not cause mortality in mice at all doses [23]. However, the extract produced abdominal constrictions, sedation, diarrhoea, and decreased motor activity [23]. The oral $\mathrm{LD}_{50}$ of Hepacare (a herbal formulation consist of Olax subscorpioidea and Capsicum frutescens) was $3807.89 \mathrm{mg} / \mathrm{kg}$ [62].

\section{Sub-acute toxicity on Olax subscorpioidea}

The sub-acute oral administration of the ethanol leaf extract of Olax subscorpioidea (250, 500, 750, and 1000 $\mathrm{mg} / \mathrm{kg}$ ) caused a significant decrease in the serum levels of alanine aminotransferase (ALT) and total bilirubin at 250 and $500 \mathrm{mg} / \mathrm{kg}$, respectively [63]. The extract caused a significant increase in ALP at 500, 750, and $1000 \mathrm{mg} /$ $\mathrm{kg}$ and increased plasma albumin levels at $1000 \mathrm{mg} / \mathrm{kg}$ [63]. There was also a significant reduction in mean corpuscular haemoglobin (MCH), lymphocyte (LYMP), white blood cell (WBC), and haemoglobin (HB). However, the neutrophils (NEU) significantly increased at $1000 \mathrm{mg} / \mathrm{kg}$. The extract did not significantly change the levels of red blood cells (RBC), packed cell volume (PCV), mean corpuscular volume (MCV), platelet (PLT), and mean corpuscular haemoglobin concentration $(\mathrm{MCHC})$. Similarly, there were no histopathological changes in the livers and kidney at all doses [63].

Abiodon et al. also reported the sub-acute toxicity effects of Hepacare (a herbal formulation consisting of Olax subscorpioidea and Capsicum frutescens) [62]. The herbal product has no effect on the body weight, relative heart, liver, kidney, spleen, and lung weights [62]. The ALP remarkably elevated at the dose of $750 \mathrm{mg} / \mathrm{kg}$. Besides, ALT, AST, ALP, bilirubin, and total protein significantly increased at the dose $2500 \mathrm{mg} / \mathrm{kg}$. The effects of the herbal combination on haematological parameters showed a significant elevation in monocytes counts with no effects on PCV, WBC, neutrophils, and lymphocytes [62]. The herbal product also revealed an evidence of hepatic and renal damage after 28-day period pf administration. In contrast, Adebayo et al. reported a lack of hepatotoxicity and renal toxicity of Olax subscorpioidea following the 28-day treatment [63].

\section{Genotoxicity study on Olax subscorpioidea}

The n-hexane leaf extract of O. Olax subscorpioidea (50 $\mathrm{mg} / \mathrm{kg}$ ) significantly reduced the DNA fragmentation in both the liver and testis compared with the control group [44]. Additionally, the extract produced a significant reduction in the levels of $\mathrm{HB}, \mathrm{PCV}, \mathrm{RBC}, \mathrm{NEU}$, and monocytes (MID), suggestive of deleterious effects of the extract on blood production, which may result in anaemia. However, the extract significantly increased WBC, LYMP, MCV, MCH, and MCHC compared with the control group [44].

\section{Conclusion}

Studies on Olax subscorpioidea have established some of the plant's ethnopharmacological uses and provided its therapeutic potentials against many diseases. However, there are limited studies on its pharmacological activities that could further validate many reported folkloric claims. Therefore, detailed pharmacological investigations are required in the future on different parts of the plant to validate their traditional uses. Few studies were conducted to identify and isolate the phytochemical compounds present in different parts of the plant. Besides, detailed pharmacological investigations to explore their biological effects were lacking. Therefore, there is a need for more research in the future on bioassay-guided fractionation, isolation, and characterization of the extracts and fractions of Olax subscorpioidea to determine the active compounds responsible for the pharmacological activities. Moreover, the available isolated compounds could be screened for detailed pharmacological activities in animal models to explore their mechanisms of actions and molecular targets that would enable the discovery of lead compounds to develop novel therapeutic agents. Human clinical trials should also be performed to establish the clinical safety and efficacy of Olax subscorpioidea for use in the treatment of various diseases. However, the plant has the potential of causing toxicity through interfering with haematological parameters. Therefore, it should be used cautiously in patients at high risk of blood-related disorders such as anaemia. Also, further toxicity evaluations (chronic, mutagenicity, carcinogecity, teratogenicity, reproductive toxicity) of all parts of this plant are needed. Besides, more researches are required to standardize the appropriate dosage of Olax subscorpioidea for the claimed therapeutic use in traditional medicine.

\section{Abbreviations}

ABTS: 2,2-Azino-bis-3-ethylbenthiazoline-6-sulphonic acid; AChE: Acetylcholinesterase; ALP: Alkaline phosphatase; ALT: Alanine aminotransferase; ATP: Adenosine triphosphate; BChE: Butyrylcholinesterase; 
$\mathrm{CCl}_{4}$ : Carbon tetrachloride; CFA: Complete Freund's adjuvant; CNS: Central nervous system; DNA: Deoxyribonucleic acid; DPPH: 1,1-Diphenyl-2-picrylhydrazyl; EGF: Epidermal growth factor; ESR: Erythrocyte sedimentation rate; FRAP: Ferric reducing antioxidant power; FST: Forced swimming test; GABA: Gamma-amino-butyric acid; GAE/g: Gallic acid equivalent per gram of the extract; GGT: Gamma-glutamyl transferase; GSH: Glutathione;

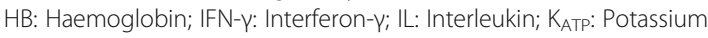
adenosine triphosphate; $\mathrm{LD}_{50}$ : Median lethal dose; LYMP: Lymphocytes; MDA: Malondialdehydes; MCH: Mean corpuscular haemoglobin; MCHC: Mean corpuscular haemoglobin concentration; MCV: Mean corpuscular volume; MID: Monocytes; MRSA: Methicillin-resistant S. aureus; NEU: Neutrophils; NO: Nitric oxide; OFT: Open field test; PCV: Packed cell volume; PLT: Platelet; QAE/g: Quercetin equivalent per gram of dried extract; RBC: Red blood cell; SGOT: Serum glutamate oxaloacetate transaminase; SGPT: Serum glutamate pyruvate transaminase; SOD: Superoxide dismutase; STDs: Sexually transmitted diseases; TBARS: Thiobarbituric acid reactive substances; TNF: Tumour necrosis factor:; TPC: Total polyphenol content; TST: Tail suspension test; VEGF: Vascular endothelial growth factor; WBC: White blood cells; WHO: World Health Organization

\section{Acknowledgements}

The authors are thankful to all members of Young Pharmacists Scholars (YPS), a mentorship forum for their continuous support and guidance.

\section{Authors' contributions}

MHA: conceptualization, designing of the work, writing of the original draft, and editing. AlJ: critically reviewed the whole manuscript. OYA: writing and review. JMS: writing and review. MM: writing and review. SM: writing and review. SM: writing and review. AAB: writing and review. ASW: writing and review. MA: writing. $A M U$ : writing. All the authors have read and approved the manuscript.

\section{Funding}

Not applicable

\section{Availability of data and materials}

Not applicable

\section{Declarations}

Ethics approval and consent to participate

Not applicable

\section{Consent for publication}

Not applicable

\section{Competing interests}

The authors declare that they have no competing interests.

\section{Author details}

'Department of Pharmacology and Therapeutics, Ahmadu Bello University, Zaria, Kaduna, Nigeria. ${ }^{2}$ School of Pharmacy and Pharmacology, University of Tasmania, Hobart, Tas 7005, Australia. ${ }^{3}$ College of Pharmacy, Riyadh Elm University, Riyadh 11681, Saudi Arabia. ${ }^{4}$ Department of Pharmacology and Therapeutics, Bayero University, Kano, Nigeria. ${ }^{5}$ School of Pharmaceutical Sciences, Universiti Sains Malaysia, 11800 Penang, Pulau Pinang, Malaysia. ${ }^{6}$ Department of Clinical Pharmacy and Pharmacy Practice, Ahmadu Bello University, Zaria, Kaduna, Nigeria. ${ }^{7}$ Faculty of Veterinary Medicine, Ahmadu Bello University, Zaria, Kaduna, Nigeria. ${ }^{8}$ Department of Pharmacology, School of Medical Sciences, Universiti Sains Malaysia, 16150 Kota Bharu, Kelantan, Malaysia. ${ }^{9}$ Department of Pharmacology, College of Medicine and Health Sciences, Federal University, Dutse, Jigawa, Nigeria. ${ }^{10}$ Department of Pharmacology, Bauchi State University, Gadau, Bauch State, Nigeria.

\section{Received: 23 January 2021 Accepted: 18 May 2021}

\section{Published online: 05 June 2021}

\section{References}

1. Dutra RC, Campos MM, Santos ARS, Calixto JB (2016) Medicinal plants in Brazil: pharmacological studies, drug discovery, challenges and perspectives. Pharmacol Res 112:4-29. https://doi.org/10.1016/j.phrs.2016.01.021
2. Ogbonnia SO, Olayemi SO, Anyika EN, Enwuru VN, Poluyi OO (2009) Evaluation of acute toxicity in mice and subchronic toxicity of hydroethanolic extract of Parinari curatellifolia Planch (Chrysobalanaceae) seeds in rats. African J Biotechnol 8(9):1800-1806. https://doi.org/10.5897/A JB2009.000-9257

3. Raskin I, Ribnicky DM, Komarnytsky S, llic N, Poulev A, Borisjuk N, Brinker A, Moreno DA, Ripoll C, Yakoby N, O'Neal JM, Cornwell T, Pastor I, Fridlender B (2002) Plants and human health in the twenty-first century. Trends Biotechnol 20(12):522-531. https://doi.org/10.1016/S0167-7799(02)02080-2

4. El Kabbaoui M, Chda A, El-Akhal J, Azdad O, Mejrhit N, Aarab L, Bencheikh R, Tazi A (2017) Acute and sub-chronic toxicity studies of the aqueous extract from leaves of Cistus ladaniferus L. in mice and rats. J Ethnopharmacol 209: 147-156. https://doi.org/10.1016/j.jep.2017.07.029

5. Atanasov AG, Waltenberger B, Pferschy-Wenzig EM, Linder T, Wawrosch $C$, Uhrin P, Temml V, Wang L, Schwaiger S, Heiss EH, Rollinger JM, Schuster D, Breuss JM, Bochkov V, Mihovilovic MD, Kopp B, Bauer R, Dirsch VM, Stuppner H (2005) Discovery and resupply of pharmacologically active plant-derived natural products: a review. Biotechnol Adv 33(8):1582-1614. https://doi.org/10.1016/i.biotechadv.2015.08.001

6. Thomford NE, Senthebane DA, Rowe A, Munro D, Seele P, Maroyi A, Dzobo K (2018) Natural products for drug discovery in the 21st century: Innovations for novel drug discovery. Int J Mol Sci 19(6):1578. https://doi. org/10.3390/ijms19061578

7. Ayandele AA, Adebiyi AO (2007) The phytochemical analysis and antimicrobial screening of extracts of Olax subscorpioidea. African J Biotechnol 6(7):868-870. https://doi.org/10.4314/ajb.v6i7.56922

8. Victoria UC, Michael UC, Johnny MU (2010) Evaluation of the antiulcer activity of Olax subscorpioidea Oliv. roots in rats. Asian Pac J Trop Med 3(1): 13-16. https://doi.org/10.1016/S1995-7645(10)60022-3

9. Odoma S, Zezi AU, Danjuma NM, Ahmed A, Magaji MG (2016) Elucidation of the possible mechanism of analgesic actions of butanol leaf fraction of Olax subscorpioidea Oliv. J Ethnopharmacol 199:323-327. https://doi.org/10.1 016/j.jep.2016.12.052

10. Odoma S (2016) Analgesic, anti-inflammatory and other pharmacological activities of methanol leaf extract of Olax subscorpioidea Oliv (Olacaceae) in laboratory animals. Ahmadu Bello University, Zaria, Nigeria http://kubanni.a bu.edu.ng/jspui/handle/123456789/8827

11. Soladoye MO, Amusa NA, Raji-Esan SO, Chukwuma EC, Taiwo AA (2010) Ethnobotanical survey of anti-cancer plants in Ogun State, Nigeria. Ann Biol Res 1(4):261-273

12. Orabueze IC, Amudalat AA, Usman AA (2016) Antimicrobial value of Olax subscorpioidea and Bridelia ferruginea on microorganism isolates of dental infection. J Pharmacogn Phytochem 5(5):398-406 https://pdfs.sema nticscholar.org/fa0a/208689347ff1999e2d9d4c9378b4c246e695.pdf

13. Adeoluwae AG, Aderibigbe OA, Bakre AO (2015) Evaluation of antidepressant-like effect of Olax subscorpioidea Oliv (Olacaceae) extract in mice. Drug Res 65(06):306-311. https://doi.org/10.1055/s-0034-1382010

14. Gbadamosi IT, Raji LA, Oyagbemi AA, Omobowale TO (2017) Hypolipidemic effects of Olax subscorpioidea oliv. root extract in experimental rat model. African J Biomed Res 20(3):293-299

15. Kazeem Ml, Ayeleso AO, Mukwevho E (2015) Olax subscorpioidea Oliv. leaf alleviates postprandial hyperglycaemia by inhibition of a-amylase and aglucosidase. Int J Pharmacol 11(5):484-489. https://doi.org/10.3923/ijp.2015.4 84.489

16. Sonibare M, Gbile Z (2008) Ethnobotanical survey of anti-asthmatic plants in South Western Nigeria. African J Tradit Complement Altern Med 5(4):340345. https://doi.org/10.4314/ajtcam.v5i4.31288

17. Mojirayo RI (2017) In vivo anti-plasmodial activity and histopathological analysis of water and ethanol extracts of a polyherbal antimalarial recipe. J Pharmacogn Phyther 9(6):87-100. https://doi.org/10.5897/jpp2 017.0449

18. Adeoluwa OA, Aderibigbe AO, Olonode ET (2014) Antinociceptive property of Olax subscorpioidea Oliv (Olacaceae) extract in mice. J Ethnopharmacol 156:353-357. https://doi.org/10.1016/j.jep.2014.08.040

19. Okoli RI, Aigbe O, Ohaju-Obodo JO, Mensah JK (2007) Medicinal herbs used for managing some common ailments among Esan people of Edo State, Nigeria. Pakistan J Nutr 6(5):490-496. https://doi.org/10.3923/pjn.2007.490.496

20. Ibrahim JA, Muazzam I, Jegede IA, Kunle OF, Okogun JI (2007) Ethnomedicinal plants and methods used by Gwandara tribe of Sabo Wuse in Niger State, Nigeria, to treat mental illness. African J Tradit Complement Altern Med 4(2):211-218. https://doi.org/10.4314/ajtcam.v4i2.31210 
21. Konan K, Justin NK, Lydie B, Souleymane M, Francis YA, David NJ (2015) Hepatoprotective and in vivo antioxidant activity of Olax subscorpioidea Oliv. (Olacaceae) and Distemonathus benthamianus Baill. (Caesalpiniaceae). Pharmacogn Mag 11(41):111-116. https://doi.org/10.4103/0973-1296.149723

22. Saliu JA, Olabiyi AA (2016) Aqueous extract of Securidaca longipendunculata oliv. and Olax subscropioidea inhibits key enzymes (acetylcholinesterase and butyrylcholinesterase) linked with alzheimer's disease in vitro. Pharm Biol 55(1):252-257. https://doi.org/10.1080/13880209.2016.1258426

23. Ishola IO, Akinyede A, Lawal SM, Popoola TD (2015) Antinociceptive and anti-inflammatory effects of Olax subscorpioidea Oliv. (Olacaceae) leaf extract in rodents: possible mechanisms of antinociceptive action. West African J Pharm 26(1):99-112

24. Dzoyem JP, Tchuenguem RT, Kuiate JR, Teke GN, Kechia FA, Kuete V (2014) In Vitro and In Vivo antifungal activities of selected Cameroonian dietary spices. BMC Complement Altern Med 14(1):58. https://doi.org/10.1186/14726882-14-58

25. Wisdom N, Bassey E, Jelani F, Ishaku G, Uwem U, Joseph S (2016) Biochemical studies of Ocimum sanctum and Olax subscorpioidea leaf extracts. Br J Pharm Res 12(4):1-9. https://doi.org/10.9734/bjpr/2016/27804

26. Oyedapo OO, Famurewa AJ (1995) Antiprotease and membrane stabilizing activities of extracts of Fagara zanthoxyloides, Olax subscorpioidea and Tetrapleura tetraptera. Pharm Biol 33(1):65-69. https://doi.org/10.3109/13 880209509088150

27. Ezeani NN, Ibiam UA, Orji OU, Igwenyi IO, Aloke C, Alum E, Aja PM, Ugwu OPC (2019) Effects of aqueous and ethanol root extracts of Olax subscopioidea on inflammatory parameters in complete Freund's adjuvantcollagen type II induced arthritic albino rats. Pharmacogn J 11(1):16-25. https://doi.org/10.5530/pj.2019.1.4

28. Popoola TD, Awodele O, Babawale F, Oguns O, Onabanjo O, Ibanga I, Godwin H, Oyeniyi T, Fatokun AA, Akinloye O (2019) Antioxidative, antimitotic, and DNA-damaging activities of Garcinia kola stem bark, Uvaria chamae root, and Olax subscorpioidea root used in the ethnotherapy of cancers. J Basic Clin Physiol Pharmacol 31(1):1-11. https://doi.org/10.1515/ jbcpp-2019-0073

29. Adeoluwa OA, Aderibigbe AO, Agu GO (2016) Pharmacological evaluation of central nervous system effects of ethanol leaf extract of Olax subscorpioidea in experimental animals. Drug Res 66(4):203-210. https://doi. org/10.1055/s-0035-1564137

30. Nazifi AB, Saidi O, Ismail HF (2015) Evaluation of anticonvulsant effects of methanolic extract of Olax subscorpioidea Oliv. leaves in chicks and mice. J Pharm Bioresour 12(2):165-171. https://doi.org/10.4314/jpb.v12i2.12

31. Adeoluwa AO, Aderibigbe OA, Agboola IO, Olonode TE, Ben-Azu B (2019) Butanol fraction of Olax subscorpioidea produces antidepressant effect: evidence for the involvement of monoaminergic neurotransmission. Drug Res 69(1):53-60. https://doi.org/10.1055/a-0651-7939

32. Ayoola MD, Adebajo AC, Obuotor TO, Fleischer T (2017) Antihyperglycaemic and antioxidant activities of Nigerian antidiabetic plants. J Sci Technol 37(2):71-84. https://doi.org/10.4314/just.v37i2.6

33. Popoola TD, Awodele O, Omisanya A, Obi N, Umezinwa C, Fatokun AA (2016) Three indigenous plants used in anticancer remedies, Garcinia kola Heckel (stem bark), Uvaria chamae P. Beauv. (root) and Olax subscorpioidea Oliv. (root) show analgesic and anti-inflammatory activities in animal models. J Ethnopharmacol 194:440-449. https://doi.org/10.1016/j.jep.2016. 09.046

34. Garandi B, Fankam AG, Nayim P, Wamba BEN, Mbaveng AT, Kuete V (2018) Anti-staphylococcal activity and antibiotic-modulating effect of Olax subscorpioidea, Piper guineense, Scorodophloeus zenkeri, Fagara leprieurii, and Monodora myristica against resistant phenotypes. Investig Med Chem Pharmacol 1(2):1-10. https://doi.org/10.31183/imcp.2018.00017

35. Odoma S, Zezi AU, Danjuma NM, Ahmed A (2014) Analgesic and antiinflammatory properties of methanol leaf extract of Olax suscorpioidea Oliv (Olacaceae) in mice and rats. J Pharmacol Trop Ther 4(1):29-37

36. Koné WM, Vargas M, Keiser J (2012) Anthelmintic activity of medicinal plants used in Côte d'Ivoire for treating parasitic diseases. Parasitol Res 110(6): 2351-2362. https://doi.org/10.1007/s00436-011-2771-z

37. Odoma S, Zezi AU, Danjuma NM, Ahmed A (2015) Analgesic and antiinflammatory activities guided-fractionation of Olax suscorpioidea leaf extract in mice and rats. Niger J Pharm Sci 14(1):30-43. https://doi.org/10.1 016/j.nijps.2015.09.004

38. Adegbite OS, Akinsanya YI, Kukoyi AJ, Iyanda-Joel WO, Daniel OO, Adebayo $\mathrm{AH}$ (2015) Induction of rat hepatic mitochondrial membrane permeability transition pore opening by leaf extract of Olax subscorpioidea. Pharmacognosy Res 7(1):S63-S68. https://doi.org/10.4103/0974-8490.157998

39. Fankam JM, Kuete AG, Voukeng V, Pages IK (2011) Antibacterial activities of selected cameroonian plants and their synergistic effects with antibiotics against bacteria expressing MDR phenotypes. Evidence-Based Complement Altern Med 11(104):1-11. https://doi.org/10.1155/2012/623723

40. Mojirayo RI, Titus AO, Ebenezer OD (2015) Assessment of chemical compositions of three antimalarial plants from Akure, Southwestern Nigeria: a preliminary study. African J Plant Sci 9(8):313-319. https://doi.org/10. 5897/ajps2015.1297

41. Konan K, David NJ, Souleymane M, Ahoua Y, Félix YH, Joseph DA (2013) In vitro antioxidant activity and phenolic contents of the leaves of Olax subscorpioidea and Distemonanthus benthamianus. Res J Pharm Biol Chem Sci 4(4):1419-1430

42. Womeni HM, Djikeng FT, Tiencheu B, Linder M (2013) Antioxidant potential of methanolic extracts and powders of some Cameroonian spices during accelerated storage of soybean oil. Adv Biol Chem 3(3):304-313. https://doi. org/10.4236/abc.2013.33034

43. Ji T, Ji WW, Wang J, Chen HJ, Peng X, Cheng KJ, Qiu D, Yang WJ (2021) A comprehensive review on traditional uses, chemical compositions, pharmacology properties and toxicology of Tetrastigma hemsleyanum. J Ethnopharmacol 264:113247. https://doi.org/10.1016/j.jep.2020.113247

44. Oladipupo AR, Alaribe CS, Balogun OT, Akere HT, Ayanda FA, Toye ET, Coker HAB (2018) Investigation of chemical, genotoxic and haematological properties of secondary metabolites from $n$-Hexane extract of Olax subscorpioidea oliv. (Olacaceae) leaves. Trop J Nat Prod Res 2(12):506-511. https://doi.org/10.26538/tjnpr/v2i12.3

45. Cantrell CL, Berhow MA, Phillips BS, Duval SM, Weisleder D, Vaughn SF (2003) Bioactive crude plant seed extracts from the NCAUR oilseed repository. Phytomedicine 10(4):325-333. https://doi.org/10.1078/0944711 03322004820

46. Cryan JF, Markou A, Lucki I (2002) Assessing antidepressant activity in rodents: recent developments and future needs. Trends Pharmacol Sci 23(5): 238-245. https://doi.org/10.1016/S0165-6147(02)02017-5

47. Montgomery SL, Bowers WJ (2012) Tumor necrosis factor-alpha and the roles it plays in homeostatic and degenerative processes within the central nervous system. J Neuroimmune Pharmacol 7(1):42-59. https://doi.org/10.1 007/s11481-011-9287-2

48. Wang Y, Xu F, Gainetdinov RR, Caron MG (1999) Genetic approaches to studying norepinephrine function: knockout of the mouse norepinephrine transporter gene. Biol Psychiatry 46(9):1124-1130. https://doi.org/10.1016/ S0006-3223(99)00245-0

49. Dulawa SC, Janowsky DS (2019) Cholinergic regulation of mood: from basic and clinical studies to emerging therapeutics. Mol Psychiatry 24(5):694-709. https://doi.org/10.1038/s41380-018-0219-x

50. Stone EA, Grunewald GL, Lin YAN, Ahsan R, Rosengarten H, Kramer HK, Quartermain D (2003) Role of epinephrine stimulation of CNS a1 -adrenoceptors in motor activity in mice. Synapse 49(1):67-76. https://doi. org/10.1002/syn.10212

51. Yamada J, Sugimoto Y, Yamada S (2004) Involvement of dopamine receptors in the anti-immobility effects of dopamine re-uptake inhibitors in the forced swimming test. 504(3):207-211. https://doi.org/10.1016/j.ejphar.2 004.09.057

52. Mole RA, Brooks BW (2019) Global scanning of selective serotonin reuptake inhibitors: occurrence, waste water treatment and hazards in aquatic systems. Environ Pollut 25:1019-1031. https://doi.org/10.1016/j.envpol.2019.04.118

53. Sánchez-Mateo CC, Bonkanka CX, Hernández-Pérez M, Rabanal RM (2006) Evaluation of the analgesic and topical anti-inflammatory effects of Hypericum reflexum L. fil. J Ethnopharmacol 107(1):1-6. https://doi.org/10.101 6/j.jep.2006.01.032

54. Odoma S, Zezi AU, Danjuma NM, Abubakar A, Magaji MG (2020) Effects of aqueous and butanol leaf fractions of Olax subscorpioidea oliv. On inflammatory cytokines in wistar rats. Trop. J. Nat. Prod. Res. 4(9):606-611. https://doi.org/10.26538/tjnpr/v4i9.19

55. Idowu PA, Okanlawon BM, Salam HO (2020) Susceptibility pattern of Escherichia coli from urinary tract infections to antibiotics and methanol extracts of Olax subscorpioidea and Sida corymbosa. J Pharm Bioresour 17(1): 75-80. https://doi.org/10.4314/jpb.v17i1.12

56. Banjo O, Oyelami LA, Ashidi J, Babatunde OI (2018) Phytochemical components and antibacterial activity of Olax subscorpioidea root on selected bacterial pathogens. FUOYE J Pure Appl Sci 3(1):355-364 
57. Hu W, Kavanagh JJ (2003) Anticancer therapy targeting the apoptotic pathway. Lancet Oncol 4(12):721-729. https://doi.org/10.1016/S1470-2045(03 01277-4

58. Olubode OS, Ayoola DO (2020) Phytotoxic effects of aqueous extracts of Olax subscorpioidea Oliv. on seed germination and growth parameters of maize (Zea mays L.). J Agric Ecol Res Int 21:22-28. https://doi.org/10.9734/ja eri/2020/v21i530144

59. Han CT, Kim DY, Nam C, Moon SH, Park SH, Han KG, Lee HY, Bae HM, Park CB, So JH, Kang S, Kang JK (2020) Acute and 13-week subchronic toxicity studies of hot-water extract of Cynanchi wilfordii Radix in Sprague-Dawley rats. Toxicol Res 36(1):89-98. https://doi.org/10.1007/s43188-019-00018-0

60. Sharma V, Sarkar IN (2013) Bioinformatics opportunities for identification and study of medicinal plants. Brief Bioinform 14(2):238-250. https://doi. org/10.1093/bib/bbs021

61. Yuet Ping K, Darah I, Chen Y, Sreeramanan S, Sasidharan S (2013) Acute and subchronic toxicity study of Euphorbia hirta L. methanol extract in rats. Biomed Res Int 2013:182064-182014. https://doi.org/10.1155/2013/182064

62. Adebayo AH, Ashano EE, Yakubu OF, Okubena O (2017) Pro-inflammatory and toxicological evaluation of Hepacare Oे in mice. J Taibah Univ Med Sci 12(4):313-323. https://doi.org/10.1016/j.jtumed.2017.02.004

63. Abiodun HA, Oluwatobi SA, Joseph AOO, Oyetomiwa OF, Kenechukwu BO (2014) Toxicological evaluation of extract of Olax subsorpioidea on albino Wistar rats. African J Pharm Pharmacol 8(21):570-578. https://doi.org/10. 5897/ajpp2013.3900

\section{Publisher's Note}

Springer Nature remains neutral with regard to jurisdictional claims in published maps and institutional affiliations.

\section{Submit your manuscript to a SpringerOpen ${ }^{\circ}$ journal and benefit from:}

- Convenient online submission

- Rigorous peer review

- Open access: articles freely available online

- High visibility within the field

- Retaining the copyright to your article

Submit your next manuscript at $\boldsymbol{\nabla}$ springeropen.com 